\title{
Education for healthcare associated infection prevention and control in Croatia: how to start from the beginning
}

\author{
Smilja Kalenic ${ }^{1}$, Ana Budimir ${ }^{1,2}$ \\ 1. University of Zagreb School of Medicine, Department for Medical Microbiology \\ 2. University Hospital Centre Zagreb, Reference Centre for Hospital Infections \\ doi: 10.3396/ijic.V7i2.014.11
}

\begin{abstract}
Introduction
Infection prevention and control in hospitals started in former Yugoslavia (Croatia being a part of it) some 40 years ago as an initiative of Croatian infectious disease physicians, microbiologists, epidemiologists and nurses. However, this initiative was lead by a few enthusiastic people, and although several meetings were held, ${ }^{1-3}$ very little happened besides some sporadic efforts in some hospitals.
\end{abstract}

According to bylaws issued in the 1970s, in former Yugoslavia, Infection prevention and Control was the remit of epidemiologists from the Public Health Institutes, acting on information based on environmental swabs in hospitals. Healthcare associated infections (HCAl) were supposed to be reported by physicians directly to the Public Health Institutes, so very little or no infections were reported whatsoever. When, in the 1990s, Croatia became an independent country, there was no systematic infection control in hospitals.
This was first addressed in $1994,{ }^{4}$ when a new bylaw on healthcare associated infection prevention and control was issued, instituting a National Committee, Infection Control Committees in hospitals and creating the nurse-hygienist role. In the second issue of this bylaw, ${ }^{5}$ in 1998, this nursing post was for the first time called "infection prevention and control nurse", and it was stated that he/she should have "additional education", without specifying what kind of education, nor who would provide it. In 2002 the third publication of this bylaw, ${ }^{6}$ mentioned for the first time a physician "with experience in HCAI prevention and control".

It is expected that a fourth revision will occur in 2011. It is hoped that this revision will state that both the nurse and the physician with responsibilities for infection prevention and control should have some formal education in this field, ideally with at least a basic course of 300 hours duration (based on the British experience), and also should be engaged in a continuing education programme in infection prevention and control.

\section{Corresponding author}

Smilja Kalenic

Department for Medical Microbiology, University of Zagreb School of Medicine, 10000 Zagreb, Salata 3b

Mobile: +385 98301 443, Phone: +385 14590 115, Fax: +385 14590 130, E-mail: skalenic@mef.hr 


\section{Postgraduate education for professionals in HCAI prevention and control}

\section{Continuing medical education courses}

In early 1990-ties the Croatian Society for Medical Microbiology and Parasitology started organizing a yearly 2-3 day course of continuing medical education (CME) in the field of HCAI prevention and control for microbiologists. The assumption was that microbiologists actually are the first to know about the causative agent of infection in patients. The University of Zagreb School of Medicine recognized these courses, and issued certificate of recertification to the attendees, which did not translate into other benefits such as higher salaries nor better positions.

The Reference Centre for Hospital Infections (RCHI) was formed in 1998. This is a national body formed by Ministry of Health, and one of the duties is education. So RCHI responded to the previous year's bylaw, and in 1999 initiated a programme of education, in the form of short 2-3 day courses in specific topics in infection prevention and control. Two courses were organized per year, one for nurses only, and another for nurses and physicians. Topics were different from course to course, and included prevention of surgical site infections, hand hygiene, environmental hygiene, Urinary Tract Infections, Ventilator Associated Pneumonia, and Intensive Care Unit related infections. The last one, "Prevention of ICU infections" was held in cooperation with the International Federation of Infection Control (IFIC) in 2000.

In addition, to support these activities and facilitate the acquisition of knowledge in the field of HCAl prevention and control, the $\mathrm{RCHI}$ translated two books into Croatian language. ${ }^{7,8}$

\section{Basic course for nurses}

During those CME courses it became gradually obvious that many nurses as well as some physicians had major gaps in their basic knowledge of microbiology, epidemiology and infectious diseases - three medical fields necessary for good infection prevention and control skills. Neither the School of Medicine nor the School of Nursing had sufficient experience in organising more comprehensive courses than the CME ones. Therefore, in 2005 the $\mathrm{RCHI}$ decided to take the lead, with the aim of offering a comprehensive basic course for nurses who were already employed as infection control nurses.

The course was entitled "Basic education of nurses for infection control", with approximately 20 nurses in each intake. It is a 300 hours course, organised in the following format:

- formal lecture (\% of time) $\quad 10 \%$

- seminars (\% of time) 20\%

- practical experiences ( $\%$ of time) $20 \%$

- general discussion (\% of time) $10 \%$

- self organized study (\% of time) $40 \%$

The course is held over 6 months, with one week per month of direct teaching (formal lectures, seminars, practical work and general discussions) and with self organized study in between, practicing infection control in their own hospitals and completing some "homework" - e.g. working on some topic agreed upon with the teachers in advance. The following month students were expected to present this "homework" in front of the whole group, thus benefitting from peer comments.

Main contents provided by the course are presented in Table I. By the end of 2010, three courses had been held, and 66 nurses $(62 \%$ of all infection control nurses in Croatia) passed these courses. A certificate, valid for recertification as a general nurse and recognized by the Nurses Chamber, is issued on completion. Although this does not bring material benefits, such as higher salaries or better positions, it is recognised that there are clear benefits through the learning of basic principles of HCAI prevention and control applicable to everyday practice.

\section{Masters diploma for nurses}

During 2008 the School of Nursing in Zagreb developed several masters programmes, one of those being a masters programme for the prevention and control of HCAI. All master level courses have a common first year with general topics in nursing, the second year being subject specific.

For the HCAI course, the programme was developed 
Table I: Content of the Basic education course for nurses for infection control

\begin{tabular}{ll} 
Topic & Main content \\
\hline Microbiology & $\begin{array}{l}\text { Characteristics of microorganisms, survival in environment, } \\
\text { pathogenesis of infections, entry site and routes of transmission } \\
\text { of microorganisms. Obligatory pathogens and opportunistic } \\
\text { pathogens. Samples used for microbiological analysis. Sensitivity } \\
\text { of microorganisms to antimicrobial drugs and disinfectants. } \\
\text { Multiresistant microorganisms. Normal human flora. }\end{array}$ \\
\hline Host and infection & $\begin{array}{l}\text { Immunity to infection. Disorders of immune response in patients } \\
\text { with existing disease leading to hospitalization. Vaccines. Main } \\
\text { clinical and laboratory characteristics of infections in patients. }\end{array}$ \\
\hline Epidemiology and biostatistics & Basic principles of infectious disease epidemiology. \\
& $\begin{array}{l}\text { Epidemiologic categories significant for healthcare-associated } \\
\text { infection prevention and control. Isolation. Surveillance of }\end{array}$ \\
healthcare-associated infections. Outbreak management. Basic \\
methods of biostatistics used in control of healthcare-associated \\
infections.
\end{tabular}

Special chapters in healthcare-associated Surgical site infections, intravascular catheter-related infection prevention and control infections, catheter-related infections of urinary tract, healthcare associated pneumonia, infections caused by agents transferred by blood and bodily fluids, gastrointestinal infections, infections of other systems, infections caused by special pathogens (Mycobacterium tuberculosis, methicillinresistant Staphylococcus aureus (MRSA), vancomycin-resistant enterococci (VRE), multiresistant gram-negative bacilli), infections in special patient population (ICU, burn units, newborns, paediatric patients, oncologic patients, AIDS patients, transplant patients, infections in dentistry, infections in special therapeutic and diagnostic procedures like anaesthesia, endoscopy, transfusion). 


\begin{tabular}{ll}
$\begin{array}{l}\text { Table I continued } \\
\text { Topic }\end{array}$ & Main content \\
\hline $\begin{array}{l}\text { Healthcare-associated infections in } \\
\text { community settings }\end{array}$ & $\begin{array}{l}\text { Dentistry, general practice offices, long-term healthcare facilities } \\
\text { (LTCFs), nursing homes, home care etc }\end{array}$ \\
\hline Health-care workers health & $\begin{array}{l}\text { Sharps incidents, infections transmitted by blood and bodily } \\
\text { fluids, vaccination preventable diseases; personal protective } \\
\text { equipment, standard precautions measures }\end{array}$ \\
\hline Hospital kitchen & HACCP as an integral part of hospital infection control \\
\hline Laundry & Procedures for transport and processing of laundry \\
\hline Waste management in hospital & $\begin{array}{l}\text { Types of clinical waste; waste at point of generation and in } \\
\text { accumulation areas, sharps disposition }\end{array}$ \\
\hline Organization of hospital infection control Laws, bylaws. Infection Control Team, Infection Control \\
Committee, Infection Control Programme
\end{tabular}

by several Croatian experts in HCAI prevention and control, lead by the RCHI. The course is competency based, based on those from the project "Improving Patient Safety in Europe" (IPSE). ${ }^{9}$ During the second year, there are 580 hours of direct teaching, including 300 hours of practical work. There are also several elective modules to be completed, and the students are expected to complete a master thesis. All together, both years provide 120 credit points, according to the Bologna process (60 credit points per year is obligatory for high education in European Union). ${ }^{10,11}$ The first generation of students started this masters programme in the academic year 2010/2011, so we expect our first infection control nurses with a masters degree in 2012.

\section{PhD for physicians}

After graduating from medical school, physicians can also go on to get a $\mathrm{PhD}$ degree in infection control. A number of young people, mainly microbiologists, but also a few surgeons, have either completed or are currently working on their thesis in the field of infection control.

\section{and nursing students}

It is important for medical as well as for nursing students to learn about HCAI prevention and control during their undergraduate studies. But often too busy curriculum programmes do not allow for such topics, especially if their teachers are not aware of the importance of infection prevention, as is the case in Croatian medical and nursing schools. Only a few hours instruction regarding prevention of HCAI during their microbiology course is provided at Nursing Schools, with hand hygiene taught during ward practice. In medical schools, one or two hours of hand hygiene practice is obligatory during their third year microbiology course in the context of laboratory work, and a further two hours of seminars about HCAI prevention is included in the fourth year obligatory course of clinical microbiology. The University of Zagreb School of Medicine has had an elective, problem-based 30 hour course "I wash my hands of healthcare associated infections" since 2005, and every year some $10 \%$ of all students elect to take this course, usually attracted by the slightly provocative title.

\section{Conclusion}


In the last 20 years much has been done in Croatia to promote and facilitate the education for professionals in $\mathrm{HCAl}$ prevention and control, with a focus on nurses' education. At the beginning teachers were learning together with student nurses, and student nurses were slowly becoming teachers for younger colleagues. Starting in 2012, a number of nurses will have a masters degree that will be very important for teaching and research in HCAl prevention and control. There is so far no basic course for Physicians, and the challenge will be to develop it over the next few years. And finally, for the undergraduate studies, our goal is to ensure that HCAls are recognized as important and that course in infection prevention and control become a requirement for undergraduate nursing and medical students.

\section{References}

1. Radovi Klinike za zarazne bolesti, Sv.1. Hospitalne infekcije, Zagreb 1972.

2. Hospitalne infekcije. Klinika za zarazne bolesti, Zagreb 1973.

3. Prvi seminar: Kucne infekcije u bolnickim i izvanbolnickim ustanovama, Zadar 1987.

4. Pravilnik o nacinu i uvjetima obavljanja mjera za sprecavanje i suzbijanje bolnickih infekcija, Narodne Novine 31/1994; http://narodne-novine.nn.hr (accessed 30 December 2010)

5. Pravilnik o nacinu i uvjetima obavljanja mjera za sprecavanje i suzbijanje bolnickih infekcija, Narodne Novine 17/1998; http://narodne-novine.nn.hr (accessed 30 December 2010)

6. Pravilnik o nacinu i uvjetima obavljanja mjera za sprjecavanje i suzbijanje bolnickih infekcija, Narodne Novine 93/2002; http://narodne-novine.nn.hr (accessed 30 December 2010)

7. IFIC: Kontrola infekcije: temeljna nacela i edukacija. Prijevod 2. izdanja, Zagreb 2004. (Original: Infection Control: Basic Concepts and Training. Second Edition, IFIC, International Federation of Infcetion Control, 2003)

8. Damani N.N. Prirucnik o postupcima kontrole infekcija. Prijevod 2. izdanja, Zagreb 2004. (Original: N.N.Damani. Manual of Infcetion Control Procedures, 2nd Edition, Greenwich Medical Media Limited, London, 2003)

9. European Core Curriculum for training for Infection Control Practitioners. Version 5th May 2008. Available from: http:// ecdc.europa.eu/ipse/Working\%20packages/WP1/Core\%20 Curriculum\%20Report.pdf (accessed: 30 December 2010)

10. Bologna Declaration. Available from: http://ec.europa.eu/ education/policies/educ/bologna/bologna.pdf (accessed 12 January 2011)

11. Davies R. The Bologna process: The quiet revolution in nursing higher education. Nurse Education Today 2008; 28: 935-942. 